\title{
Deteksi Dini Risiko Ibu Hamil dengan Kartu Skor Poedji Rochjati dan Pencegahan Faktor Empat Terlambat
}

\author{
Gede Danu Widarta', Muhammad Ardian Cahya Laksana', Agus Sulistyono', Windhu Purnomo² \\ 'Departemen Obstetri dan Ginekologi, Fakultas Kedokteran Universitas Airlangga, RSUD Dr. Soetomo, Surabaya \\ ${ }^{2}$ Program Studi Administrasi dan Kebijakan Kesehatan, Fakultas Kesehatan Masyarakat, Universitas Airlangga, Surabaya
}

\section{ABSTRAK}

Tujuan: menganalisis kasus kematian maternal di RSUD Dr. Soetomo tahun 2011 - 2013 dengan tiga penyebab terbanyak (perdarahan pasca salin, preeklampsia berat dan penyakit jantung) ditinjau dari skor KSPR dan faktor empat terlambat.

Bahan dan Metode: Penelitian ini merupakan penelitian retrospektif observasional dengan desain studi deskriptif. Objek pada penelitian ini merupakan pasien yang meninggal sebagai kasus kematian maternal di RSUD Dr. Soetomo tahun 2011-2013, dengan jumlah 58 orang. Variabel penelitian ini adalah tingkat risiko kehamilan berdasarkan KSPR, faktor empat terlambat dan kematian maternal.

Hasil: Pada penelitian ini didapatkan seluruh kasus kematian maternal mengandung unsur faktor risiko dalam KSPR dan faktor empat terlambat. KRST merupakan kelompok faktor risiko terbanyak $(55,2 \%)$, diikuti oleh KRT $39,7 \%$ dan KRR 5,2\%. Faktor terlambat mendeteksi tanda bahaya ditemukan sebanyak $82,8 \%$, terlambat mengambil keputusan merujuk 56,9\%, dan terlambat sampai di tempat rujukan $15,5 \%$. Faktor terlambat mendapat pertolongan di tempat rujukan terakhir tidak ditemukan pada penelitian ini.

Simpulan: KSPR masih relevan digunakan untuk deteksi dini faktor risiko ibu hamil. Pencegahan faktor empat terlambat penting untuk menurunkan angka kematian maternal

Kata kunci: Kematian maternal, KSPR, faktor empat terlambat

\section{ABSTRACT}

Objectives: to analyze the maternal deaths in Dr. Soetomo Hospital years 2011 - 2013 with the three most common causes (severe preeclampsia, hemorrhage post partum and heart disease) in terms of Poedji Rochjati Score Card (PRSC) and the factors of four lates.

Materials and methods: This study was a retrospective observational descriptive study design. The objects of this study were 58 patient who died as maternal deaths in Dr. Soetomo Hospital in years 2011-2013. The variables of this study were the risk level of pregnancy based on PRSC, factors of four lates and maternal mortality.

Results: In this study, all cases of maternal deaths contained elements of risk factors in PRSC and a factor of four lates. PRSC is the most risk factor group (55.2\%), followed by KRT $(39.7 \%)$ and $(5.2 \%)$ KRR. Factor of being delayed detecting danger signs were found as much as $82.8 \%$, delayed taking the decision to refer $56.9 \%$, and being late to the referral hospital was $15.5 \%$. Factor of being late to obtain medical care at the last refferral hospital was not found in this study.

Conclusion: PRSC remains relevant to use for early detection of risk factors in pregnant women. The prevention of four lates factors is important to reduce maternal deaths.

Keywords: maternal death, Poedji Rochjati Score Card, factor of four lates

Correspondence: Gede Danu Widarta, Departemen Obstetri dan Ginekologi, Fakultas Kedokteran Universitas Airlangga, RSUD Dr. Soetomo, J1. Prof dr Moestopo 6-8, Surabaya 60286, Indonesia. email: gede_widarta2008@yahoo.com

\section{PENDAHULUAN}

Berdasarkan hasil Survei Demografi Kesehatan Indonesia (SDKI), angka kematian maternal meroket dari 228 pada tahun 2007 menjadi 359 per 100.000 kelahiran hidup pada tahun 2013. Sedangkan MDGs menargetkan sebesar 102 per 100.000 kelahiran hidup pada tahun 2015. Tahun 2012 AKI di Jatim telah turun yaitu dari 104/100.000 kelahiran hidup (2011) turun menjadi 97/100.000 kelahiran hidup. Berarti Jatim telah mendahului dari komitmen pencapaian target MDGs yakni tahun 2015 yang hanya 102/100.000 kelahiran hidup. ${ }^{1}$

Angka kematian maternal melahirkan di Surabaya masih tinggi. Pada 2011 AKI di Surabaya 104/100.000 kelahiran hidup. Walaupun demikian seperti halnya Jawa Timur pada umumnya AKI di Surabaya telah jauh lebih rendah daripada AKI nasional. Tetapi karena jumlah penduduk yang cukup besar maka Jawa Timur dan Surabaya pada khususnya tetap merupakan penyumbang kematian maternal nasional yang cukup banyak. RSUD Dr. Soetomo merupakan rumah sakit pemerintah terbesar dan terlengkap di Jawa Timur dan merupakan rumah sakit rujukan tersier pusat rujukan untuk Indonesia timur. Selama tahun 2011 - 2013 di RSUD Dr. Soetomo didapatkan 176 kasus kematian maternal. Tahun 2011 didapatkan 47 kematian maternal, 60 pada tahun 2012 dan 69 pada tahun 2013. Dari berbagai penyakit penyebab kematian maternal sebagian besar penyakit dapat dideteksi dini dan diantisipasi pemburukannya selama kehamilan sampai nifas. Pada beberapa penyakit memang sulit diprediksi pemburukannya seperti SLE. Bahkan ada penyakit yang memang tidak boleh hamil seperti pada ibu dengan kelainan jantung. Serta pada kasus yang membutuhkan kecepatan ekstra dalam proses rujukan dan penanganannya seperti pada kasus perdarahan setelah melahirkan 
(perdarahan pasca salin/PPS). Selama tahun 2011 2013 PEB, PPS dan penyakit jantung selalu berada pada peringkat tiga besar penyebab kematian maternal. ${ }^{1}$

Beberapa pendekatan faktor risiko untuk mencegah kematian maternal sudah dikembangkan di Indonesia. Faktor 4 terlalu dan 3 terlambat merupakan konsep faktor risiko yang sudah dikenal cukup lama di Indonesia. Begitu juga dengan Kartu Skor Poedji Rochjati telah digunakan secara umum di Surabaya untuk mendeteksi secara dini faktor risiko pada kehamilan yang dapat berpengaruh buruk pada ibu hamil maupun janin yang dikandungnya. Faktor empat terlalu sudah masuk dalam Kartu Skor Poedji Rochjati. ${ }^{2}$

Di luar negeri beberapa ahli berpendapat adanya faktor 4 terlambat yang mempengaruhi kematian maternal. Faktor 4 terlambat itu adalah: terlambat mendeteksi tanda bahaya, terlambat mengambil keputusan merujuk, terlambat sampai di tempat rujukan, dan terlambat mendapatkan pertolongan di tempat rujukan. Pada keterlambatan mendeteksi masalah diantisipasi dengan melakukan edukasi kepada ibu hamil dan keluarganya, sehingga dapat mengenali tanda bahaya. Keterlambatan dalam mengambil keputusan diantisipasi dengan mengubah cara pengambilan keputusan. Memperbaiki sistem transportasi sehingga akses ke pusat pelayanan kesehatan dapat lebih mudah dan cepat dan tidak terjadi lagi keterlambatan sampai di tempat rujukan. ${ }^{3}$

\section{BAHAN DAN METODE}

Populasi kasus adalah kasus kematian maternal dengan tiga penyebab terbanyak (perdarahan pasca salin, preeklampsia berat dan penyakit jantung) di RSUD Dr. Soetomo tahun 2011 - 2013, jumlahnya 109 orang. Peneliti memutuskan melakukan total sampling pada penelitian ini, dengan kriteria inklusi kasus kematian maternal hamil, bersalin dan atau dalam masa nifas yang terjadi pada kurun waktu tanggal 1 Januari 2011 pukul 00.01 sampai tanggal 31 Desember 2013 pukul 24.00, kematian maternal terjadi di RSUD Dr. Soetomo, kasus kematian maternal merupakan kasus rujukan, dan kasus terdiagnosa sebagai PEB, penyakit jantung dan atau perdarahan pasca salin dengan atau tanpa komplikasinya, seperti eklampsia, HELLP syndrome, edam paru, gagal jantung, syok hipovolemik dan sebagainya.

Sedangkan kriteria eksklusi adalah kasus kematian maternal hamil, bersalin dan atau dalam masa nifas yang didahului oleh kecelakaan apapun seperti kecelakaan lalu lintas, kejadian yang tidak disengaja dan bunuh diri, kasus kematian maternal hamil, bersalin dan atau dalam masa nifas yang didahului oleh tindak kejahatan seperti pembunuhan, kasus death on arrival, dan kasus kematian maternal yang tidak ditemukan rekam medisnya atau tidak lengkap. Data merupakan data sekunder yang diperoleh dari rekam medis data pada Satgas PENAKIB RSUD Dr. Soetomo. Hasil penelitian dikelompokkan dan diorganisasikan dengan menggunakan program SPSS versi 22.

\section{HASIL DAN PEMBAHASAN}

KRST merupakan kelompok risiko ibu hamil yang jumlahnya paling banyak pada kasus kematian maternal diikuti oleh KRT dan KRR paling sedikit. Hal tersebut merupakan sesuatu yang wajar, karena meninggal merupakan kondisi yang selalu didahului oleh keadaan penyakit yang sangat berat dengan faktor risiko yang sangat tinggi. Namun masih didapatkan kehamilan dengan risiko rendah, hal ini membuktikan bahwa tidak ada kehamilan yang tidak berisiko. Sesuai dengan sistem skor pada KSPR, bahwa 2 merupakan skor minimal pada setiap kehamilan. ${ }^{2}$

Untuk faktor risiko KSPR pada penelitian ini ditemukan jumlah yang bervariasi. Berikut urutannya dari yang paling banyak ditemukan hingga yang paling sedikit, yaitu komplikasi kehamilan saat ini sebanyak 54 kasus $(93,1 \%)$, kehamilan patologis saat ini 35 kasus $(60,3 \%)$, penyakit pada ibu hamil 26 kasus $(44,8 \%)$, terlalu tua hamil pertama atau selanjutnya 17 kasus $(29,3 \%)$, riwayat obstetri jelek 14 kasus $(24,1 \%)$, terlalu banyak hamil 6 kasus (10,3\%), terlalu lama hamil lagi 5 kasus $(8,6 \%)$, riwayat persalinan patologis 4 kasus $(6,9 \%)$, terlalu lambat hamil pertama 3 kasus $(5,2 \%)$, terlalu cepat hamil lagi 3 kasus $(5,2 \%)$, terlalu muda hamil 1 kasus $(1,7 \%)$, dan terlalu pendek, untuk faktor ini tidak ditemukan pada keseluruhan kasus.

Faktor risiko komplikasi kehamilan saat ini terdapat pada 54 kasus, yaitu 93,1\% dari 58 kasus. Hal ini dapat dimengerti bahwa sebagian besar keadaan meninggal tentunya didahului oleh keadaan dengan berbagai komplikasi penyakit. Ditemukan sebanyak 35 kasus $(60,3 \%)$ dengan faktor risiko kehamilan patologis saat ini. Hal ini dapat disebabkan oleh komplikasi yang terjadi tentunya didahului oleh faktor risiko dalam kehamilan.

Sedangkan faktor risiko yang ditemukan pada kisaran $<50 \%$, kemungkinan disebabkan faktor risiko tersebut tidak berhubungan langsung dengan penyebab kematian maternal seperti pada dua faktor risiko sebelumnya. Mungkin juga disebabkan, karena faktor risiko yang ditemukan pada kisaran $<50 \%$ merupakan faktor risiko yang mudah untuk dideteksi. Bahkan hanya dengan wawancara dan sekilas penglihatan. Contohnya pada 
faktor risiko terlalu pendek, sangat mudah dideteksi. Sehingga tidak ada kasus kematian maternal dengan faktor risiko terlalu pendek, karena dapat dideteksi secara dini dengan mudah. ${ }^{4}$

Untuk faktor empat terlambat ditemukan juga jumlah yang bervariasi, dengan rentang kisaran cukup besar. Berikut urutannya dari yang terbanyak sampai yang paling sedikit: terlambat mendeteksi tanda bahaya 48 kasus $(82,8 \%)$, terlambat mengambil keputusan merujuk sebanyak 33 kasus $(56,9 \%)$, terlambat sampai di tempat rujukan sebanyak 9 kasus $(15,5 \%)$ dan tidak ditemukan keterlambatan mendapatkan pertolongan di tempat rujukan.

Faktor terlambat mendeteksi tanda bahaya mempunyai jumlah terbanyak diantara faktor empat terlambat yaitu 48 kasus. Juga mempunyai proporsi yang besar pada setiap penyebab kematian. Hal ini sesuai dengan pendapat para ahli sebelumnya bahwa, faktor ini merupakan awal mula dari keterlambatan 3 faktor lainnya. Urutan jumlah setiap faktor tersebut dari yang terbanyak sampai yang paling sedikit sesuai dengan pendapat ahli mengenai urutan terjadinya faktor keterlambatan. Dari keempat faktor empat terlambat faktor terlambat mendeteksi tanda bahaya terjadi paling awal dan mempengaruhi faktor empat terlambat lainnya secara berurutan. ${ }^{5}$

Kasus yang terdiagnosis sebagai PEB dan PEB \& penyakit jantung cenderung semakin banyak terdeteksi pada kelompok risiko yang semakin tinggi. Sedangkan pada kasus PPS dan PEB \& PPS cenderung sebaliknya. Hal ini mungkin disebabkan karena PEB dan penyakit jantung memang terjadi pada saat gravid, sedangkan PPS terjadi pasca persalinan. Sehingga faktor yang berpengaruh pada PPS juga merupakan faktor yang timbul dan berpengaruh pasca salin. Contohnya penolong persalinan, tindakan saat persalinan maupun pasca persalinan. Kasus dengan penyebab murni penyakit jantung cenderung terdeteksi sebagai KRT. Hal ini disebabkan karena pada KSPR semua penyakit ibu hamil diberikan skor 4. Sehingga kurang sesuai dengan derajat kemungkinan kematian maternal akibat penyakit jantung.

Pada semua kasus kecuali yang mengandung unsur diagnosis PPS, cenderung terjadi keterlambatan dalam mengambil keputusan merujuk. Hal ini mungkin disebabkan, pada kejadian PPS baik petugas maupun keluarga pasien dapat melihat sendiri betapa mengerikannya aliran darah pada seorang ibu hamil dengan PPS. Sehingga hal tersebut yang dapat mempercepat petugas maupun keluarga dalam pengambilan keputusan. Dengan kata lain hal tersebut merupakan faktor yang intimidatif untuk pengambilan keputusan merujuk.
Complete agreement mudah didapatkan pada keadaan emergency seperti perdarahan ataupun distosia sehingga keluarga akan cenderung setuju untuk segera melakukan rujukan. ${ }^{6}$

Sebaliknya, pada semua kasus kematian maternal, kecuali murni disebabkan oleh PPS, cenderung tidak terjadi keterlambatan sampai di tempat rujukan terakhir. Hal ini mungkin disebabkan pada kasus dengan penyebab murni PPS, faktor risiko kehamilan tidak ditemukan karena kurang telitinya petugas kesehatan. Bisa juga disebabkan memang tidak ada faktor risiko, tetapi terjadi keteledoran pada saat persalinan atau masa nifas. Dengan tidak ditemukannya faktor risiko, akan terjadi kurangnya persiapan transportasi ke tempat rujukan yang berakibat keterlambatan sampai di tempat rujukan. Persiapan tersebut dapat berupa persiapan biaya untuk transportasi dan biaya lainnyan yang bukan saja menyangkut pengobatan. Biaya lain tersebut harus dikeluarkan yang berhubungan dengan rujukan (opportunity cost) seperti biaya untuk transportasi ke tempat rujukan, biaya makan dan tempat tinggal bagi keluarga yang mengantar serta biaya lainnya. ${ }^{6}$

Pada semua kasus cenderung tidak ditemukan keterlambatan mendapat pertolongan di tempat rujukan. Hal ini mungkin disebabkan, pada umumnya tempat rujukan terakhir sudah mendapatkan informasi sebelumnya. Disamping itu petugas kesehatan di tempat rujukan terakhir mempunyai keterampilan dan keahlian yang lebih baik serta jumlah yang lebih banyak.

Semakin tinggi tingkat risiko ibu hamil, semakin banyak ditemukan faktor keterlambatan mendeteksi tanda bahaya. Hal ini mungkin disebabkan keahlian petugas pada layanan kesehatan primer yang kurang baik atau memang kasus tersebut perlu penanganan oleh dokter ahli. Sehingga mungkin diperlukan tenaga dokter ahli melakukan screening ibu hamil pada periode tertentu dan usia kehamilan tertentu. Semakin banyak ditemukannya faktor keterlambatan dalam mendeteksi tanda bahaya akan berakibat juga pada terlambatnya pengambilan keputusan untuk merujuk. Sebaliknya, pada KRST dan KRT cenderung tidak terjadi keterlambatan sampai di tempat rujukan, bila dibanding-kan dengan KRR. Hal ini mungkin disebabkan pada KRST dan KRT baik petugas maupun keluarga menjadi lebih waspada dan mempersiapkan segala sesuatunya sebaik mungkin.

Pada semua kasus ditemukan kecenderungan, semakin tinggi tingkat risiko kehamilan, semakin banyak ditemukan keterlambatan mendapat pertolongan di tempat rujukan terakhir. Hal ini mungkin disebabkan karena semakin tinggi tingkat risiko kehamilan, maka semakin banyak pula masalah yang harus ditangani. 
Sehingga dengan kemampuan dan jumlah petugas yang tetap, tetapi tingkat risiko kehamilan yang semakin tinggi, maka akan mengurangi kecepatan penanganannya.

Pada semua kasus kecuali PPS, cenderung datang ke RSUD Dr. Soetomo pada kehamilan trimester III. Begitu juga dengan kelompok risiko ibu hamil dan faktor empat. Hal ini memperkuat pentingnya pemeriksaan, screening dan KIE oleh dokter SpOG pada trimester II, sebelum terjadinya komplikasi dan kematian maternal.

Pada kasus yang murni disebabkan oleh PPS, cenderung lebih banyak terjadi pada persalinan spontan, yaitu 2 diantara 3 kasus. Hal ini mungkin disebabkan oleh kurangnya ketelitian dalam mendeteksi adanya indikasi SC. Pada salah satu kasus terdapat indikasi bayi besar yang mungkin menyebabkan kemacetan persalinan, terbukti bahwa bayi yang dilahirkan seberat 4100 gram. Selain itu mungkin juga disebabkan kurangnya keahlian penolong atau deteksi faktor risiko yang kurang baik sejak awal kehamilan.

Pada semua diagnosa, kelompok risiko, maupun kasus yang mengandung faktor empat terlambat pasien cenderung untuk memeriksakan kehamilannya pada bidan. Bahkan pada semua diagnosa kecuali dengan diagnosa PEB dan penyakit jantung. Hal tersebut terjadi juga pada KRT dan KRST yang seharusnya diperiksa oleh minimal seorang dokter. Sedangkan Dokter SpOG hanya memeriksa 5 pasien $(21,8 \%)$ dari KRT dan 4 pasien yaitu $12,5 \%$ dari KRST. Bahkan masih ada 1 pasien yang tidak pernah memeriksakan kehamilannya sama sekali. Hal tersebut mungkin disebabkan oleh pemikiran masyarakat yang masih belum benar mengenai pelayanan kesehatan maupun sistem asuransinya, sehingga mereka mungkin takut untuk memeriksakan kehamilan ke dokter karena menganggap biayanya mahal meskipun di pusat layanan kesehatan pemerintah.

Pada semua kasus pasien cenderung meninggal pada saat > 48 jam setelah masuk RSUD Dr. Soetomo. Kecuali pada kasus yang disebabkan murni karena PPS. Hal tersebut terjadi juga bahkan pada kasus KRR dan yang tidak mengandung faktor empat terlambat. Bila diasumsikan pada kasus kematian maternal yang terjadi $>48$ jam lebih banyak dipengaruhi faktor pada pusat layanan kesehatan terakhir, maka dapat disimpulkan terjadi juga kelemahan pada tempat rujukan terakhir. sehingga dapat diasumsikan terjadi kelemahan pada semua sektor pada kasus kematian maternal, baik itu di sektor pasien, keluarga pasien, layanan kesehatan primer, sekunder dan tersier
Secara ringkas, penelitian ini menemukan bahwa pada kasus kematian maternal dengan tiga penyebab terbanyak di RSUD Dr. Soetomo tahun 2011 - 2013, KRST 55,2\%, KRT 39,7\% dan KRR 5,2\%. KRST merupakan kelompok risiko kehamilan terbanyak yang ditemukan. Faktor keterlambatan mendeteksi tanda bahaya sebanyak 82,8\% dari 58 kasus kematian maternal. Faktor ini merupakan faktor keterlambatan yang paling banyak ditemukan. Faktor keterlambatan mengambil keputusan merujuk sebanyak $56,9 \%$, faktor keterlambatan sampai di tempat rujukan sebanyak $15,5 \%$, dan faktor keterlambatan mendapat pertolongan di tempat rujukan terakhir tidak ditemukan dalam penelitian ini.

Kemudian, ditemukan keterlambatan mendeteksi tanda bahaya pada 90,6\% dari KRST, 73,9\% dari KRT dan $33,3 \%$ dari KRR. Semakin tinggi tingkat risiko kehamilan, semakin banyak ditemukan keterlambatan dalam mendeteksi tanda bahaya. Keterlambatan mengambil keputusan merujuk ditemukan pada 65,6\% dari KRST, 47,8\% dari KRT dan 33,3\% dari KRR. Semakin tinggi tingkat risiko kehamilan, semakin banyak ditemukan keterlambatan dalam mengambil keputusan merujuk. Keterlambatan sampai di tempat rujukan pada ditemukan pada $9,4 \%$ dari KRST, $17,4 \%$ dari KRT dan $66,7 \%$ dari KRR. Semakin rendah tingkat risiko kehamilan, semakin banyak ditemukan keterlambatan sampai di tempat rujukan.

\section{SIMPULAN}

KSPR masih relevan digunakan untuk deteksi dini faktor risiko ibu hamil. Pencegahan faktor empat terlambat penting untuk menurunkan angka kematian maternal.

\section{DAFTAR PUSTAKA}

1. Irawan A. Perbandingan Pengaruh Determinan Dekat, Antara dan Jauh Terhadap Kematian Maternal Di Kota Surabaya Tahun 2011-2012. Penelitian untuk meraih gelar SpOG. 2013.

2. Rochjati P. Skrining antenatal pada ibu hamil: pengenalan faktor risiko. Surabaya: Airlangga University Press; 2003.

3. Eltahir A. Refusing to accept maternal mortality. Boston: Pathfinder International; 2009.

4. Rochjati P. Bunga rampai obstetri dan ginekologi sosial: sistem rujukan dalam pelayanan kesehatan reproduksi. Jakarta: Yayasan Bina Pustaka Sarwono Prawirohardjo; 2005.

5. Ghebrehiwet M, Morrow RH. Delay In Seeking And Receiving Emergency Obstetric Care In 
Majalah Obstetri \& Ginekologi, Vol. 23 No. I Januari - April 2015 : 28-32

Eritrea. Journal of Eritrean Medical Association. 2007;9(1):8-13.

6. Kowalewski M, Jahn A, Kimatta S. Why Do at Risk Mothers Fail to Reach Referral Level?
Barriers Beyond Distance and Cost. African Journal of Reproductive Health. 2000;4(1):100-9. 